\title{
Remote Sensing of Above-Ground Biomass
}

\author{
Lalit Kumar 1,* (1) and Onisimo Mutanga ${ }^{2}$ \\ 1 Ecosystem Management, School of Environmental and Rural Science, University of New England, \\ Armidale NSW 2351, Australia \\ 2 School of Agricultural, Earth and Environmental Sciences, University of KwaZulu Natal, \\ P. Bag X01 Scottsville, Pietermaritzburg 3209, South Africa; MutangaO@ukzn.ac.za \\ * Correspondence: lkumar@une.edu.au; Tel.: +612-6773-5239
}

Received: 8 September 2017; Accepted: 8 September 2017; Published: 10 September 2017

\section{Importance of Above-Ground Biomass}

Accurate measurement and mapping of biomass is a critical component of carbon stock quantification, climate change impact assessment, suitability and location of bio-energy processing plants, assessing fuel for forest fires, and assessing merchandisable timber. While above-ground biomass includes both live and dead plant material, most of the recent research effort on biomass estimation has focussed on the 'live' component (live trees) due to the prominence of this component. Accurate estimates of biomass is a prerequisite for better understanding of the impacts of deforestation and environmental degradation on climate change.

The Intergovernmental Panel on Climate Change (IPCC) [1] has listed five terrestrial ecosystem carbon pools involving biomass: above-ground biomass, below-ground biomass, litter, woody debris and soil organic matter. Of these five, above-ground biomass is the most visible, dominant, dynamic and important pool of the terrestrial ecosystem, constituting around $30 \%$ of the total terrestrial ecosystem carbon pool. Above-ground biomass estimation, and especially forest biomass, has received considerable attention over the last few decades because of increased awareness of climate warming and the role forest biomass plays in carbon sequestration and release of greenhouse gases due to deforestation.

Above-ground biomass estimates are the central basis for carbon inventories and most international negotiations in carbon trading schemes. Carbon trading markets require long-term information on carbon stocks, particularly on the above-ground 'live' biomass component as this is the most dynamic, changing and manipulable component of all the biomass pools. This is the 'merchantable' component of biomass.

Above-ground forest biomass accounts for between $70 \%$ to $90 \%$ of total forest biomass [2]. While soil organic matter holds two to three times more carbon than biomass on a global scale, much of the soil carbon is more protected and not easily oxidised [3]. On the other hand, above-ground biomass is in a continuous state of flux due to fire, logging, storms, landuse changes, etc., and thus contributes to atmospheric carbon fluxes to a much greater extent and so is of much greater interest. Due to this dynamism of above-ground biomass, it is necessary to monitor it continuously and not measure once and forget.

While detailed estimations of biomass is necessary for accurate carbon accounting, reliable estimation methods are few. Accurate estimates of stored carbon (biomass as dry weight is $50 \%$ carbon [4] and understanding sources and sinks can improve the accuracy of carbon flux models and thus lead to better projections of climate change and impacts. Initiatives such as Reducing Emissions from Deforestation and Forest Degradation (REDD) and REDD+ also rely heavily on above-ground biomass estimates [5,6]. REDD+ includes financing schemes and incentives with the aim of mitigating climate change by reducing deforestation and forest degradation through sustainable forest management and conservation, and enhancement of carbon stocks $[7,8]$. The countries that 
participate in the REDD+ scheme have a requirement to produce accurate estimates of their forest carbon stocks and changes.

Wildfire and fuel management are becoming an increasingly important part of forest management. Forest biomass, and especially crown biomass and the dry litter component, are important factors in any fire model. Traditionally crown biomass was a neglected component as there was much greater emphasis on the commercial component of the trees but with fire playing a more important role in environmental planning, this biomass component has gained prominence.

Biomass is also a highly abundant source of energy that is widely used around the world. Its attractiveness is that it is a renewable fuel. However, biomass resources are distributed over wide geographical regions and their qualities for energy production varies over space and time. Also, very often the resources are located far away from the centres where energy generation is required. Because of this link between distribution over space and time and centres of requirements, it is important to have accurate and consistent means of measurement methods for biomass to evaluate feasibility of biomass for energy generation.

\section{Methods of Assessing Above-Ground Biomass}

Above-ground biomass can be measured or estimated both destructively and non-destructively. In the destructive method, sometimes also known as the harvest method, the trees are actually cut down and weighed. Sometimes a selected sample of trees are harvested and estimations for the whole population are based on these, especially where there is uniformity in tree size, for example a pine plantation. The destructive method of biomass estimation is limited to a small area due to the destructive nature, time, expense and labour involved. It is also not suitable where there may be threatened flora and fauna.

The non-destructive methods include the estimation based on allometric equations or through remote imagery. Allometric equations have been developed through the use of tree dimensions [9-15], such as diameter at breast height ( $\mathrm{dbh}$ ) and tree height, however these are not very useful in heterogenous forests. Allometric equations are most useful in uniform forests or plantations with similar aged stands.

\section{Role of Remote Sensing in Mapping Above-Ground Biomass}

While biomass derived from field data measurements is the most accurate, it is not a practical approach for broad-scale assessments. This is where Remote Sensing has a key advantage. It can provide data over large areas at a fraction of the cost associated with extensive sampling and enables access to inaccessible places. Data from Remote Sensing satellites are available at various scales, from local to global, and from a number of different platforms. There are also different types of data, such as optical, radar and LiDAR, with each one having certain advantages over the others [15].

Optical Remote Sensing probably provides the best alternative to biomass estimation through field sampling due to its global coverage, repetitiveness and cost-effectiveness. Optical Remote Sensing data is available from a number of platforms, such as IKONOS, Quickbird, Worldview, SPOT, Sentinel, Landsat and MODIS. The spatial resolutions vary from less than one metre to hundreds of metres. Optical Remote Sensing data has been used by numerous researchers for biomass estimation [16-27].

Radar Remote Sensing has gained prominence for above-ground biomass estimation in recent years due to its cloud penetration ability as well as detailed vegetation structural information [15]. While airborne Synthetic Aperture Radar (SAR) systems have been operating for many years, space-borne systems such as Terra-SAR, ALOS and PALSAR have become available since 2000. This has enabled repetitiveness and cost-effectiveness. A large number of recent studies have explored the use of radar data for above-ground biomass estimation [28-44].

LiDAR is a relatively new technology that has found favour in biomass estimation. It has the ability to sample the vertical distribution of canopy and ground surfaces, providing detailed structural information about vegetation. This leads to more accurate estimations of basal area, crown size, tree 
height and stem volume. A number of studies have established strong correlations between LiDAR parameters and above-ground biomass [45-55].

\section{Purpose of this Special Issue}

Vegetation biomass plays a crucial role in understanding and monitoring ecosystem response and its contribution to the global carbon cycle. The recognition of forests as potential sinks of atmospheric carbon has resulted in numerous studies being conducted in estimating above-ground biomass or carbon stocks across varying scales. In addition, grassland biomass quantification is critical in understanding rangeland productivity as a resource for animal grazing. However, uncertainties in the Remote Sensing of AGB are high due to vegetation structural variations, heterogeneity of landscapes, seasonality and disproportionate data availability, among others. Recent developments in high resolution space-borne and air-borne satellite data have provided an opportunity to better estimate and map AGB across different spatial and temporal scales. The use of drones and UAVs has opened up avenues for super-fine resolution biomass estimation for targeted applications. Recent sensors, such as the Worldview series, now provide meter level spatial resolution while Sentinel and Landsat 8 provide free data for the whole world, opening up accessibility and more applications of Remote Sensing data, including for biomass estimation.

Remote sensing is a constantly evolving technology with new applications and methods being regularly introduced. This special issue was a call for the latest innovative methods and applications to map AGB at different scales. The range of topics included, but was not limited to, algorithm development and implementation, accuracy assessment, scaling issues (local-regional-global biomass mapping), integration of microwave (i.e., LiDAR) and optical sensors, forest biomass mapping, rangeland productivity and abundance (grass biomass, density, cover), bush encroachment biomass, seasonality and long term biomass monitoring, and climate change impacts and temporal monitoring.

\section{Summary of Papers Published in this Special Issue}

This special issue details results from a total of 15 papers that unpack the importance of Remote Sensing in biomass estimation and mapping across different spatial scales. The rich spectral, temporal and spatial information contained in satellite images has seen an improvement on productivity mapping under complex environmental conditions. Data sets used range from field spectrometers, multispectral and multi temporal images as well as microwave derived images. The data sets were combined with advanced machine learning algorithms and other state of the art processing techniques to reveal spatial and temporal biomass patterns.

A number of papers in this issue incorporated phenology in biomass estimation using Remote Sensing. Schucknecht et al. [56] used in-situ spatiotemporal biomass production and Remote Sensing to build a biomass model for the period 2001 to 2015. The phenology based seasonal NDVI was used as a proxy for biomass production and the model successfully predicted biomass at the end of the growing season. In a related study, NDVI Land Surface phenology derived from MODIS was used to model biomass in seasonal wetlands. The method was robust across different environmental conditions [57]. The use of high spatial resolution images in estimating carbon stocks across seasons was evaluated across two seasons in an abandoned agricultural land [58]. Pixel-scale vegetation indices derived from the dry season images yielded higher correlations with biomass than those derived from the wet season. The result confirms the saturation problem encountered using NDVI during biomass peak. Long term trends in biomass production are also critical in understanding the mechanism, direction and magnitude of climatic effects. Feng et al. [59] simulated potential productivity and actual productivity using Remote Sensing as well as climatic and anthropogenic data sets in Northern Tibetan Plateau between 1993 and 2011. Their results showed the importance of precipitation in regulating Net Primary Productivity.

Microwave Remote Sensing has also gained popularity in vegetation mapping in recent years. This issue presents three papers that used LiDAR and RADAR data to model vegetation biomass across 
different biomes. In a comparative study of modelling the biophysical attributes between deciduous and conifer forests, low density footprint LiDAR data successfully revealed spatial patterns of stem volume and total dry biomass [60]. Vaglio Laurin et al. [61] tested the potential of ALOS2 and NDVI to estimate above ground biomass. The objective was to solve the saturation problem experienced at low to moderate biomass levels when using JERS and ALOS SAR. The integrated SAR and NDVI improved estimation of biomass, while only a slight saturation was experienced at higher forest biomass levels. Pasture biomass was also modelled by integrating optical and X-Band radar data in an open savannah woodland [62]. The objective was to minimise the saturation problem experienced when using optical data as well as difficulties in separating dry matter from litter. TerraSAR-X (TSX) and image data from Landsat TM data from both dry and wet seasons could predict standing dry matter with high accuracy.

Optical multispectral data, with varying resolutions, was also used to estimate biomass. A multi-source satellite data approach was used to evaluate the potential of Remote Sensing in reducing biomass estimation error in an Alpine Meadow grassland [63]. Results showed that filtered MODIS NDVI data reduces biomass estimation errors and the error increases with the increasing spatial scale of investigation. Addition of Laser Altimeter data to Landsat TM in a multivariate modelling framework improved forest biomass predictions in Northern China [64]. Sibanda et al. [65] integrated texture metrics and the red edge derived indices from simulated Worldview-3 data to estimate biomass. Results showed the robustness of the model in reducing errors of prediction across all management treatments.

A total of 3 studies in this issue also applied hyperspectral data to improve biomass estimation. Jin et al. [66] used indices generated from the field spectroscopic data to calibrate the AquaCrop model for wheat yield and biomass estimation. In another study [67], fusion of Ultrasonic Sward Height and with narrow band normalized spectral index and simulated Worldview -2 data improved biomass prediction accuracy in grasslands with heterogeneous sward structure. Cheng et al. [68] showed the importance of dry matter indices in predicting biomass in canopy components of paddy rice as compared to chlorophyll indices, which saturate at high biomass levels.

Finally, this issue reports the utility of multi-angle data in improving biomass predictions. A study using multi angle CHRIS/PROBA data [69] showed that off nadir vegetation indices could predict forest biomass more accurately than the nadir derived indices. The result underscores the importance of Bidirectional Reflectance Distribution Function (BRDF) as a source of information than a source of uncertainty.

In summary, this Special Issue explored the role of Remote Sensing in estimating grassland, forest and woody biomass using a plethora of data and processing methods. Seasonality information was successfully built into biomass models with improved accuracies. The fusion of microwave and multispectral/hyperspectral data also reduced uncertainty errors in biomass estimation, especially in environments with complex canopy structure. Of critical importance is that the special issue highlighted methods and data sets that solves the problem of saturation in biomass estimation using the conventional vegetation indices [70]. The issue provides a platform for day to day methods and approaches to operationalize Remote Sensing in vegetation productivity management.

Acknowledgments: The authors thank the various contributors, reviewers and journal staff at Remote Sensing for making this Special Issue a success.

Author Contributions: The two authors contributed equally to all aspects of this paper.

Conflicts of Interest: The authors declare no conflict of interest.

\section{References}

1. Eggleston, H.S.; Buendia, L.; Miwa, K.; Ngara, T.; Tanabe, K. IPCC Guidelines for National Greenhouse Gas Inventories Volume-IV Agriculture, Forestry and other Land-Use; Institute of Global Environmental Strategies (IGES): Hayama, Japan, 2006. 
2. Cairns, M.A.; Brown, S.; Helmer, E.H.; Baumgardner, G.A. Root biomass allocation in the world's upland forests. Oecologia 1997, 111, 1-11. [CrossRef] [PubMed]

3. Davidson, E.A.; Janssens, I.A. Temperature sensitivity of soil carbon decomposition and feedbacks to climate change. Nature 2006, 440, 165-173. [CrossRef] [PubMed]

4. Houghton, R.A.; Hall, F.; Goetz, S.J. Importance of biomass in the global carbon cycle. J. Geophys. Res. 2009, 114. [CrossRef]

5. Gibbs, H.K.; Brown, S.; Niles, J.O.; Foley, J.A. Monitoring and estimating tropical forest carbon stocks: Making REDD a reality. Environ. Res. Lett. 2007, 2, 1-13. [CrossRef]

6. Koch, B. Status and future of laser scanning, synthetic aperture radar and hyperspectral remote sensing data for forest biomass assessment. ISPRS J. Photogramm. Remote Sens. 2010, 65, 581-590. [CrossRef]

7. Angelsen, A.; Hofstad, O. Inputs to the Development of a National REDD Strategy in Tanzania. Available online: http:/ / cf.tfcg.org/pubs/Angelsen2008REDD\%20Tanzania\%20rpt.pdf (accessed on 8 September 2017).

8. United Nations. Outcome of the Ad Hoc Working Group on longterm cooperative action under the convention. In Proceedings of the United Nations Framework Convention on Climate Change (2011), Durban, South Africa, 28 November-11 December 2011.

9. Nelson, B.W.; Mesquita, R.; Pereira, J.L.G.; Aquino de Sauza, S.G.; Batista, G.T.; Couto, L.B. Allometric regressions for improved estimate of secondary forest biomass in the Central Amazon. For. Ecol. Manag. 1999, 117, 149-167. [CrossRef]

10. Wang, X.C.; Ceulemans, R. Allometric relationships for below- and aboveground biomass of young Scots pines. For. Ecol. Manag. 2004, 203, 177-186.

11. Montès, N.; Gauquelin, T.; Badri, W.; Bertaudiere, V.; Zaoui, E.H. A non-destructive method for estimating above-ground forest biomass in threatened woodlands. For. Ecol. Manag. 2000, 130, 37-46. [CrossRef]

12. Navár, J. Allometric equations for tree species and carbon stocks for forests of Northwestern Mexico. For. Ecol. Manag. 2009, 257, 427-434. [CrossRef]

13. Brown, S.; Gillespie, A.R.; Lugo, A.E. Biomass estimation methods for tropical forests with applications to forest inventory data. For. Sci. 1989, 35, 881-902.

14. Basuki, T.M.; Van Laake, P.E.; Skidmore, A.K.; Hussin, Y.A. Allometric equations for estimating the above-ground biomass in tropical lowland dipterocarp forests. For. Ecol. Manag. 2009, 257, 1684-1694. [CrossRef]

15. Kumar, L.; Sinha, P.; Taylor, S.; Alqurashi, A.F. Review of the use of remote sensing for biomass estimation to support renewable energy generation. J. Appl. Remote Sens. 2015, 9. [CrossRef]

16. Thenkabail, P.S.; Stucky, N.; Griscom, B.W.; Ashton, M.S.; Diels, J.; van der Meer, B.; Enclona, E. Biomass estimations and carbon stock calculations in the oil palm plantations of African derived savannas using IKONOS data. Int. J. Remote Sens. 2004, 25, 5447-5472. [CrossRef]

17. Hyde, P.; Dubayah, R.; Walker, W.; Blair, J.B.; Hofton, M.; Hunsaker, C. Mapping forest structure for wildlife habitat analysis using multi-sensor (LiDAR, SAR/InSAR, ETM+, Quickbird) synergy. Remote Sens. Environ. 2006, 102, 63-73. [CrossRef]

18. Foody, G.M.; Boyd, D.S.; Cutler, M.E.J. Predictive relations of tropical forest biomass from Landsat TM data and their transferability between regions. Remote Sens. Environ. 2003, 85, 463-474. [CrossRef]

19. Steininger, M.K. Satellite estimation of tropical secondary forest above-ground biomass: Data from Brazil and Bolivia. Int. J. Remote Sens. 2000, 21, 1139-1157. [CrossRef]

20. Zheng, D.; Rademacher, J.; Chen, J.; Crow, T.; Bresee, M.; Le Moine, J.; Ryu, S. Estimating aboveground biomass using Landsat 7 ETM data across a managed landscape in northern Wisconsin, USA. Remote Sens. Environ. 2004, 93, 402-411. [CrossRef]

21. Baccini, A.; Friedl, M.A.; Woodcock, C.E.; Warbington, R. Forest biomass estimation over regional scales using multisource data. Geophys. Res. Lett. 2004, 31. [CrossRef]

22. Dong, J.; Kaufmann, R.K.; Myneni, R.B.; Tucker, C.J.; Kauppi, P.E.; Liski, J.; Buermann, W.; Alexeyev, V.; Hughes, M.K. Remote sensing estimates of boreal and temperate forest woody biomass: Carbon pools, sources, and sinks. Remote Sens. Environ. 2003, 84, 393-410. [CrossRef]

23. Calvão, T.; Palmeirim, J.M. Mapping Mediterranean scrub with satellite imagery: Biomass estimation and spectral behaviour. Int. J. Remote Sens. 2004, 25, 3113-3126. [CrossRef] 
24. Lu, D. Aboveground biomass estimation using Landsat TM data in the Brazilian Amazon. Int. J. Remote Sens. 2005, 26, 2509-2525. [CrossRef]

25. Rahman, M.M.; Csaplovics, E.; Koch, B. An efficient regression strategy for extracting forest biomass information from satellite sensor data. Int. J. Remote Sens. 2005, 26, 1511-1519. [CrossRef]

26. Li, M.; Tan, Y.; Pan, J.; Peng, S. Modeling forest aboveground biomass by combining spectrum, textures and topographic features. Front. For. China 2008, 3, 10-15. [CrossRef]

27. Muukkonen, P.; Heiskanen, J. Estimating biomass for boreal forests using ASTER satellite data combined with standwise forest inventory data. Remote Sens. Environ. 2005, 99, 434-447. [CrossRef]

28. Ranson, K.J.; Sun, G. Mapping biomass of a northern forest using multifrequency SAR data. IEEE Trans. Geosci. Electron. 1994, 32, 388-396. [CrossRef]

29. Imhoff, M.L.; Johnson, P.; Holford, W.; Hyer, J.; May, L.; Lawrence, W.; Harcombe, P. BioSAR (TM): An inexpensive airborne VHF multiband SAR system for vegetation biomass measurement. IEEE Trans. Geosci. Remote Sens. 2000, 38, 1458-1462. [CrossRef]

30. Castel, T.; Guerra, F.; Caraglio, Y.; Houllier, F. Retrieval biomass of a large Venezuelan pine plantation using JERS-1 SAR data. Analysis of forest structure impact on radar signature. Remote Sens. Environ. 2002, 79, 30-41. [CrossRef]

31. Sun, G.; Ranson, K.J.; Kharuk, V.I. Radiometric slope correction for forest biomass estimation from SAR data in the Western Sayani Mountains, Siberia. Remote Sens. Environ. 2002, 79, 279-287. [CrossRef]

32. Santos, J.R.; Freitas, C.C.; Araujo, L.S.; Dutra, L.V.; Mura, J.C.; Gama, F.F.; Soler, L.S.; Sant'Anna, S.J.S. Airborne P-band SAR applied to the aboveground biomass studies in the Brazilian tropical rainforest. Remote Sens. Environ. 2003, 87, 482-493. [CrossRef]

33. Kasischke, E.S.; Melack, J.M.; Dobson, M.C. The use of imaging radars for ecological applications-A review. Remote Sens. Environ. 1997, 59, 141-156. [CrossRef]

34. Kasischke, E.S.; Goetz, S.; Hansen, M.C.; Ozdogan, M.; Rogan, J.; Ustin, S.L.; Woodcock, C.E. Temperate and boreal forests. In Remote Sensing for Natural Resource Management and Environmental Monitoring; Ustin, S.L., Ed.; John Wiley \& Sons: Hoboken, NJ, USA, 2004; pp. 147-238.

35. Sarker, M.L.R.; Nichol, J.; Iz, H.B.; Ahmad, B.B.; Rahman, A.A. Forest biomass estimation using texture measurements of high resolution dual-polarization C-band SAR data. IEEE Trans. Geosci. Remote Sens. 2013, 51, 3371-3384. [CrossRef]

36. Buckley, J.R.; Smith, A.M. Monitoring grasslands with RADARSAT 2 quad-pol imagery. IEEE Int. Geosci. Remote Sens. Symp. 2010, 3090-3093. [CrossRef]

37. Le Toan, T.; Beaudoin, A.; Riom, J.; Guyon, D. Relating forest biomass to SAR data. IEEE Trans. Geosci. Remote Sens. 1992, 30, 403-411. [CrossRef]

38. Santos, J.R.; Lacruz, M.S.P.; Araujo, L.S.; Keil, M. Savanna and tropical rainforest biomass estimation and spatialization using JERS-1 data. Int. J. Remote Sens. 2002, 23, 1217-1229. [CrossRef]

39. Balzter, H. Forest mapping and monitoring with interferometric synthetic aperture radar (InSAR). Progr. Phys. Geogr. 2001, 25, 159-177. [CrossRef]

40. Beaudoin, A.; Le Toan, T.; Goze, S.; Nezry, E.; Lopes, A.; Mougin, E.; Hsu, C.C.; Han, H.C.; Kong, J.A.; Shin, R.T. Retrieval of forest biomass from SAR data. Int. J. Remote Sens. 1994, 15, 2777-2796. [CrossRef]

41. Harrell, P.A.; Kasischke, E.S.; Bourgeau-Chavez, L.L.; Haney, E.M.; Christensen, N.L., Jr. Evaluation of approaches to estimating aboveground biomass in Southern pine forests using SIR-C data. Remote Sens. Environ. 1997, 59, 223-233. [CrossRef]

42. Le Toan, T.; Quegan, S.; Davidson, M.W.J.; Balzter, H.; Paillou, P.; Papathanassiou, K.; Plummer, S.; Rocca, F.; Saatchi, S.; Shugart, H.; et al. The BIOMASS mission: Mapping global forest biomass to better understand the terrestrial carbon cycle. Remote Sens. Environ. 2011, 115, 2850-2860. [CrossRef]

43. Lucas, R.M.; Mitchell, A.L.; Rosenqvist, A.; Proisy, C.; Melius, A.; Ticehurst, C. The potential of L-band SAR for quantifying mangrove characteristics and change: Case studies from the tropics. Aquat. Conserv. Mar. Freshwater Ecosyst. 2007, 17, 245-264. [CrossRef]

44. Solberg, S.; Astrup, R.; Gobakken, T.; Naesset, T.; Weydahl, D.J. Estimating spruce and pine biomass with interferometric X-band SAR. Remote Sens. Environ. 2010, 114, 2353-2360. [CrossRef]

45. Patenaude, G.; Hill, R.A.; Milne, R.; Gaveau, D.L.A.; Briggs, B.B.J.; Dawson, T.P. Quantifying forest above ground carbon content using LiDAR remote sensing. Remote Sens. Environ. 2004, 93, 368-380. [CrossRef] 
46. Hall, S.A.; Burke, I.C.; Box, D.O.; Kaufmann, M.R.; Stoker, J.M. Estimating stand structure using discrete-return LiDAR: An example from low density, fire prone ponderosa pine forests. For. Ecol. Manag. 2005, 208, 189-209. [CrossRef]

47. Saremi, H.; Kumar, L.; Stone, C.; Melville, G.; Turner, R. Sub-compartment variation in tree height, stem diameter and stocking in a Pinus. radiata D. Don plantation examined using airborne LiDAR data. Remote Sens. 2014, 6, 7592-7609. [CrossRef]

48. Saremi, H.; Kumar, L.; Turner, R.; Stone, C. Airborne LiDAR derived canopy height model reveals a significant difference in radiata pine (Pinus. radiata D. Don) heights based on slope and aspect of sites. Trees 2014, 28, 733-744. [CrossRef]

49. Chen, Q.; Baldocchi, D.; Gong, P.; Kelly, M. Isolating individual trees in a savanna woodland using small footprint LiDAR data. Photogramm. Eng. Remote Sens. 2006, 72, 923-932. [CrossRef]

50. Lim, K.S.; Treitz, P.M. Estimation of above ground forest biomass from airborne discrete return laser scanner data using canopy-based quantile estimators. Scand. J. For. Res. 2004, 19, 558-570. [CrossRef]

51. Popescu, S.C. Estimating biomass of individual pine trees using airborne LiDAR. Biomass Bioenergy 2007, 31, 646-655. [CrossRef]

52. Næsset, E.; Økland, T. Estimating tree height and tree crown properties using airborne scanning laser in a boreal nature reserve. Remote Sens. Environ. 2002, 79, 105-115. [CrossRef]

53. Cohen, W.B.; Spies, T.A. Estimating structural attributes of Douglas-fir/western hemlock forest stands from Landsat and SPOT imagery. Remote Sens. Environ. 1992, 41, 1-17. [CrossRef]

54. Loos, R.; Niemann, O.; Visintini, F. Identification of partial canopies using first and last return LiDAR data. In Proceedings of the Our Common Borders-Safety, Security, and the Environment through Remote Sensing, Ottawa, ON, Canada, 28 October-1 November 2007.

55. García, M.; Riano, D.; Chuvieco, E.; Danson, M. Estimating biomass carbon stocks for a Mediterranean forest in central Spain using LiDAR height and intensity data. Remote Sens. Environ. 2010, 114, 816-830. [CrossRef]

56. Schucknecht, A.; Meroni, M.; Kayitakire, F.; Boureima, A. Phenology-based biomass estimation to support rangeland management in semi-arid environments. Remote Sens. 2017, 9, 463. [CrossRef]

57. Lumbierres, M.; Méndez, P.; Bustamante, J.; Soriguer, R.; Santamaría, L. Modeling biomass production in seasonal wetlands using MODIS NDVI land surface phenology. Remote Sens. 2017, 9, 392. [CrossRef]

58. Liu, N.; Harper, R.; Handcock, R.; Evans, B.; Sochacki, S.; Dell, B.; Walden, L.; Liu, S. Seasonal timing for estimating carbon mitigation in revegetation of abandoned agricultural land with high spatial resolution remote sensing. Remote Sens. 2017, 9, 545. [CrossRef]

59. Feng, Y.; Wu, J.; Zhang, J.; Zhang, X.; Song, C. Identifying the relative contributions of climate and grazing to both direction and magnitude of alpine grassland productivity dynamics from 1993 to 2011 on the Northern Tibetan Plateau. Remote Sens. 2017, 9, 136. [CrossRef]

60. Awaya, Y.; Takahashi, T. Evaluating the differences in modeling biophysical attributes between deciduous broadleaved and evergreen conifer forests using low-density small-footprint LiDAR data. Remote Sens. 2017, 9, 572. [CrossRef]

61. Vaglio Laurin, G.; Pirotti, F.; Callegari, M.; Chen, Q.; Cuozzo, G.; Lingua, E.; Notarnicola, C.; Papale, D. Potential of ALOS2 and NDVI to estimate forest above-ground biomass, and comparison with Lidar-derived estimates. Remote Sens. 2017, 9, 18. [CrossRef]

62. Schmidt, M.; Carter, J.; Stone, G.; O’Reagain, P. Integration of optical and X-band radar data for pasture biomass estimation in an open savannah woodland. Remote Sens. 2016, 8, 989. [CrossRef]

63. Meng, B.; Ge, J.; Liang, T.; Yang, S.; Gao, J.; Feng, Q.; Cui, X.; Huang, X.; Xie, H. Evaluation of remote sensing inversion error for the above-ground biomass of alpine meadow grassland based on multi-source satellite data. Remote Sens. 2017, 9, 372. [CrossRef]

64. Liu, K.; Wang, J.; Zeng, W.; Song, J. Comparison and evaluation of three methods for estimating forest above ground biomass using TM and GLAS data. Remote Sens. 2017, 9, 341. [CrossRef]

65. Sibanda, M.; Mutanga, O.; Rouget, M.; Kumar, L. estimating biomass of native grass grown under complex management treatments using WorldView-3 spectral derivatives. Remote Sens. 2017, 9, 55. [CrossRef]

66. Jin, X.; Kumar, L.; Li, Z.; Xu, X.; Yang, G.; Wang, J. Estimation of winter wheat biomass and yield by combining the AquaCrop model and field hyperspectral data. Remote Sens. 2016, 8, 972. [CrossRef] 
67. Moeckel, T.; Safari, H.; Reddersen, B.; Fricke, T.; Wachendorf, M. Fusion of ultrasonic and spectral sensor data for improving the estimation of biomass in grasslands with heterogeneous sward structure. Remote Sens. 2017, 9, 98. [CrossRef]

68. Cheng, T.; Song, R.; Li, D.; Zhou, K.; Zheng, H.; Yao, X.; Tian, Y.; Cao, W.; Zhu, Y. Spectroscopic estimation of biomass in canopy components of paddy rice using dry matter and chlorophyll indices. Remote Sens. 2017, 9, 319. [CrossRef]

69. Wang, Q.; Pang, Y.; Li, Z.; Sun, G.; Chen, E.; Ni-Meister, W. The potential of forest biomass inversion based on vegetation indices using multi-angle CHRIS/PROBA data. Remote Sens. 2016, 8, 891. [CrossRef]

70. Mutanga, O.; Skidmore, A.K. Narrow band vegetation indices overcome the saturation problem in biomass estimation. Int. J. Remote Sens. 2004, 25, 3999-4014. [CrossRef]

2017 by the authors. Licensee MDPI, Basel, Switzerland. This article is an open access article distributed under the terms and conditions of the Creative Commons Attribution (CC BY) license (http:/ / creativecommons.org/licenses/by/4.0/). 